\title{
NUCLEAR ENERGY IN NON-ELECTRIC POWER APPLICATIONS
}

\author{
Edward. J. Lahoda, Jason P. Mazzoccoli, Dmitry V. Paramonov \\ Westinghouse Electric Science and Technology Department \\ Pittsburgh, PA 15235-5083
}

Processes in the chemical industry and hydrogen generation were identified as potential users of heat from high temperature $\left(900^{\circ} \mathrm{C}\right)$ gas cooled reactors and light water reactors operating at $325^{\circ} \mathrm{C}$. There was no inherent technical or efficiency advantage in using nuclear power heat except for the lack of greenhouse gas emissions. In the United States, thermal energy from nuclear reactors cost $\$ 1.5$ to $\$ 3$ per million Btu. By comparison, coal is more than competitive at $\$ .70$ to $\$ 1.40$ per million Btu, oil is not competitive at $\$ 6$ per million Btu, and natural gas is close at $\$ 2$ to $\$ 4$ per million Btu. After including capital, the costs of nuclear and coal increase $50 \%$ while costs for oil and gas increase $20 \%$. Therefore, gas and coal are currently more economic process heat sources.

Hydrogen generated by nuclear energy eliminates size and mobility issues, but increases costs to $\$ 5$ to $\$ 10$ per million Btu based on energy to hydrogen generation efficiencies of $30 \%$ to $42 \%$, not including costs for the hydrogen generation equipment. High temperature, solid oxide electrolysis cells using steam and electricity from a high temperature gas cooled reactor have the highest efficiency (42\%). Using a light water reactor drops this efficiency to $30 \%$. 